\title{
Cumin (Cuminum cyminum L.): A review of its ethnopharmacology, phytochemistry
}

\author{
Abdulmutalib Alabeed Allaq ${ }^{1,{ }^{*},}$, Norrizah Jaafar Sidik ${ }^{1}$, Aziyah Abdul-Aziz ${ }^{1}$, Idris Adewale Ahmed ${ }^{2}$
}

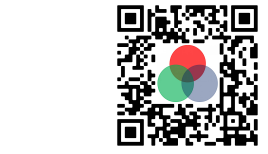

Use your smartphone to scan this QR code and download this article

${ }^{1}$ Universiti Teknologi MARA, Shah Alam

${ }^{2}$ Universiti Malaya, Kuala Lumpur Malaysia

Correspondence

Abdulmutalib Alabeed Allaq, Universiti Teknologi MARA, Shah Alam UiTM, Malaysia

Email: alabeed119@gmail.com

History

- Received: Jul 26, 2020

- Accepted: Sep 18, 2020

- Published: Sep 30, 2020

DOI : 10.15419/bmrat.v7i9.634

\section{Check for updates}

\section{Copyright}

(C) Biomedpress. This is an openaccess article distributed under the terms of the Creative Commons Attribution 4.0 International license.

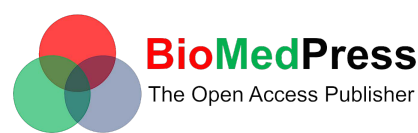

\begin{abstract}
Introduction: Cumin (Cuminum cyminum L.) is an annual plant that is not only one of the most popular seed species but also one of the oldest and most cultivated aromatic and herbaceous natural products with numerous medicinal, nutraceutical, and pharmaceutical properties. It is widely used in the beverage, food, liquor, medicine, perfume, and toiletry industries. The objective of this work was to provide a precise and up-to-date review of the ethnopharmacology, phytochemistry, and biological activities of cumin. Methods: Information was gathered from the review of relevant literature obtained from various databases, such as Science Direct, Springer, PubMed, Google, and Google Scholar. Results: The various parts of the cumin plant (leaves, shoot, root, and flowers) contain similar and different chemical compounds. Conclusion: The medicinal and health potential of cumin is mainly attributed to its antioxidant, antibacterial, antifungal, anti-inflammatory, antidiabetic, insecticide, and immunomodulatory properties. More studies are, however, required to unravel novel components and applications of cumin.

Key words: Cuminum cyminum, Cumin, Ethnopharmacology, Phytochemistry, Biological Activities
\end{abstract}

\section{INTRODUCTION}

The usage of herbal and other natural products for disease management, whether for prevention or treatment, has been known for ages ${ }^{1-5}$. Some edible herbal plant species, such as cumin (Cuminum cyminum L.), are also commonly used as food additives owing to their accessibility, safety, and usefulness ${ }^{6}$. Cumin belongs to the Apiaceae family, tribe Ammineae, and subtribe Carinae, and has $2 \mathrm{n}=14$ chromosomes $1,6,7$.

Cumin is the second most popular seed species after black pepper ${ }^{8}$. It is an annual plant and is also one of the oldest and most cultivated aromatic and herbaceous natural products with numerous medicinal, nutraceutical, and pharmaceutical properties. Cumin also has wide usage in the beverage, food, liquor, medicine, perfume, and toiletry industries ${ }^{7}$. It is native to and cultivated extensively in several places, mainly in arid and semi-arid climates, such as China, Egypt, Saudi Arabia, and the Mediterranean, as well as India and Iran. However, the largest consumer of cumin seed in the world is India while China is the largest exporter and producer. Cumin has remarkable antioxidant properties and is traditionally used as an astringent, carminative, coagulant and stimulant, as well as remedy against diarrhea, dyspepsia, epilepsy, toothache, whooping cough, flatulence, indigestion, and jaundice $6,7,9-11$.
Cumin grows to about $30-60 \mathrm{~cm}$ tall, with a glabrous, branched, and slender stem. It has compound leaves with thread-like leaflets.

It has terminal umbel inflorescence. Each cumin branch has 3-9 umbels with 5-7 umbellets, consisting of small hermaphrodite flowers which are either white or pink. It has schizocarps, i.e. fruits containing two mericarps, and about $6 \mathrm{~mm}$ long seeds which are oblong but thicker in the middle. It is mostly planted in the winter or autumn with the emergence of seedlings occurring after about 14 - 50 days. Cumin seed germination usually occurs at low temperatures $\left(<20^{\circ} \mathrm{C}\right)$ and is arrested at high temperatures ${ }^{12}$. Cumin has a weak vigor owing to its increased sensitivity to environmental stresses and because its seeds contain $10 \%$ oil $^{11}$.

The seeds of cumin are characterized by abortifacient, antispasmodic, diuretic, emmenagogic, carminative, and stomachic properties. Oleoresin from the seeds is commonly applied in crackers, sauces, meat, and sausages. The distinct and strong aroma of the seeds are responsible for its use as spices as well as other medicinal uses. The aroma is mainly due to cuminol which makes up $2.5-4.0 \%$ of the seed. The essential oils of cumin seeds primarily contain hydrocarbons and aldehydes ${ }^{8}$.

The objective of this work is to provide a precise and up-to-date review of the ethnopharmacology, phyto- 
chemistry, and biological activities of cumin. The information was gathered from the review of relevant literature obtained from various databases, such as Science Direct, Springer, PubMed, Google, and Google Scholar.

\section{Previous studies on C. cyminum}

According to literature, the quality and quantity of the compounds commonly identified in cumin vary in the various parts of the plant, such as the leaves, shoots, roots, and flowers. Though both the shoots and flowers have relatively similar terpene compounds, their concentrations are higher in the flowers. Furthermore, $\alpha$-pinene and $\beta$-pinene were not found in the roots, $\alpha$-phellandrene was notably the only detected terpenoid compound in the leaves while the flowers had the highest concentration of $\alpha$-pinene ${ }^{13}$. Cumin fruits mainly contain cellulose, fixed oil content (about 10\%), mineral elements, protein, sugar, and volatile oils (1.5\%), as well as appreciable amounts of phenolic compounds ${ }^{14}$. Formulated C. cyminum essential oil in oil-in-water nanoemulsions have demonstrated successful incorporation of lipophilic bioactive agents into functional food gels ${ }^{15}$. Natural deep eutectic solvents have also been used to significantly enhance cumin essential oil extraction with a higher yield and premium quality, as an eco-friendly and economical extraction technique ${ }^{16}$.

An increase in enzymatic (amylase, lipase, protease, and phytase) activities and antioxidant activity were achieved with saline and hot aqueous cumin extracts, as well as its oleoresin and essential oil ${ }^{17}$. Watersoluble C. cyminum polysaccharides possess lower molecular weight and effectively stimulate RAW264.7 and NK-92 cells to express interleukin (IL)-1 $\beta$, IL-6, IL-12, and tumor necrosis factor (TNF)- $\alpha$ inflammatory cytokine, and release nitric oxide ${ }^{18}$. Kedia and colleagues have also reported the fumigant, larvicidal, oviposition deterrent, ovicidal, repellent, and pupaecidal activities of C. cyminum seed essential oil, as well as its 4 main components (cymene, cumin aldehyde, $\gamma$-terpinene, and (-)- $\beta$-pinene) against Callosobruchus chinensis and Sitophilus oryzae ${ }^{19}$. Cumin is considered a very useful eco-friendly alternative for the management of insect infestation in food commodities. C. cyminum also has a remarkable antibiofilm and quorum sensing inhibitory potential against Gram-negative bacterial pathogens ${ }^{20}$. The essential oils of cumin have also demonstrated strong fumigant effects and toxicity against Anopheles gambiae $^{21}$.

\section{Ethnopharmacology of Cumin}

The common ethnomedicinal uses of cumin are summarized in Table 1. Traditionally, cumin is commonly used as a remedy against gastrointestinal, inflammatory and neurological disorders, as well as toothaches ${ }^{21}$. In Iranian traditional medicine, cumin fruits are also used as a medication for colic, diarrhea, dyspepsia and flatulence, and for stimulation of breast milk production ${ }^{14}$. It is used in Morocco for the flavoring of foods and soft dates ${ }^{10}$. It is also commonly used in Tunisia as aromatic herbs and culinary spices ${ }^{6}$, as well as in Italy for various gastrointestinal and neurological diseases ${ }^{21}$.

\section{Phytochemistry of Cumin}

The various parts of the cumin plant (leaves, shoot, root, and flowers) contain similar and different chemical compounds ${ }^{13}$. The most important chemicals which have been identified from cumin essential oils are shown in Table 2.

\section{Biological activities of Cumin}

The most important biological activities of cumin found in literature are summarized in Table 3 . They include antioxidant, antibacterial, antifungal, anti-inflammatory, antidiabetic, insecticide, and immunomodulatory properties.

\section{Antioxidant activity}

Cumin essential oils have remarkable antioxidant activities and phenolic contents which increase with maturity ${ }^{14}$. Both the pure extracts and active agents of the European cumin have also been evaluated and found to be highly effective ${ }^{29}$. Mohamed, Hamed and Fouda (2018) ${ }^{24}$ have reported that cumin extract contains $23.02 \pm 0.045 \mathrm{mg} \mathrm{GAE} / \mathrm{g}$ extract and $19 \pm$ $0.132 \mathrm{mg}$ QE/g extract for total phenolic and total flavonoids, respectively.

\section{Antimicrobial activity}

The antibacterial activity of ethanolic extracts of $C$. cyminum against Staphylococcus aureus has been reported $^{25}$. The essential oils of C. cyminum also possess antimicrobial properties ${ }^{30}$. Coronatine elicitation reportedly enhanced the yield and level of chemical components, as well as antibacterial, antifungal, antioxidant and in vitro cytotoxic activities of the cumin essential oil $^{31}$. The antifungal effects of $C$. cyminum essential oils against Candida albicans have also been reported ${ }^{22}$. According to literature, cumin has demonstrated a broad-spectrum antifungal effect against several pathogenic Candida and other fungal species $^{10,23}$. 


\begin{tabular}{|c|c|c|c|}
\hline Region & $\begin{array}{l}\text { Plant part } \\
\text { used }\end{array}$ & Traditional uses and ethnobotanical reports & References \\
\hline Iran & Spice & $\begin{array}{l}\text { Antispasmodic, lactogage and carminative ingre- } \\
\text { dient. }\end{array}$ & Tabarsa, et al. $(2020)^{18}$ \\
\hline Iran & $\begin{array}{l}\text { Cumin seed } \\
\text { (zire in } \\
\text { Iran) }\end{array}$ & $\begin{array}{l}\text { Treatment of mild digestive disorders as a carmi- } \\
\text { native, eupeptic, astringent in bronchopulmonary } \\
\text { disorders, cough remedy, as well as an analgesic. }\end{array}$ & $\begin{array}{l}\text { Minooeianhaghighi, Sepehrian } \\
\text { and Shokri }(2017)^{22}\end{array}$ \\
\hline Iran & & $\begin{array}{l}\text { stimulant, carminative, coagulant, and anti- } \\
\text { diabetic properties. }\end{array}$ & $\begin{array}{l}\text { Jafari, Sattari and Ghavamzadeh } \\
(2017)^{1}\end{array}$ \\
\hline Tunisia & Seed & $\begin{array}{l}\text { Aromatic herbs and culinary spices, stimulant, } \\
\text { carminative, astringent, and as a remedy against } \\
\text { indigestion, flatulence, and diarrhea. }\end{array}$ & Rebey et al. $(2017)^{6}$ \\
\hline Italy & Seeds & $\begin{array}{l}\text { Aromatic herbs for toothaches, gastrointestinal, } \\
\text { and neurological diseases. }\end{array}$ & Benelli et al. $(2018)^{21}$. \\
\hline Morocco & Seeds & Flavoring of foods especially soft dates. & Petretto et al. $(2018)^{10}$. \\
\hline
\end{tabular}

\section{Antidiabetic activity}

The supplementation of C. cyminum has reportedly improved fasting blood glucose level and glycosylated hemoglobin readings ${ }^{1}$. C. cyminum essential oil was also reported to exhibit maximum antidiabetic inhibition activity of $\alpha$-amylase ${ }^{32}$.

\section{Anti-inflammatory activity}

According to literature, treatments supplemented with C. cyminum have a profound effect on several inflammatory biomarkers, such as adiponectin, highsensitivity C-reactive protein (hsCRP), and TNF$\alpha^{1,26}$. Srinivasan $(2018)^{27}$ has also reported a detailed anti-inflammatory activity of C. cyminum.

\section{Insecticide activity}

Cumin essential oils possess effective insecticide activity against adult Myzus persicae and Musca domestica $^{21}$.

\section{Immunomodulatory activity}

Cumin is an effective immunomodulatory agent whose administration significantly and dosedependently increased the $\mathrm{CD}^{+}$and $\mathrm{CD}^{+} \mathrm{T}$ cell count and modulated $\mathrm{T}$ lymphocyte expression ${ }^{28}$. The detailed immunomodulatory and other beneficial properties of C. cyminum have also been reported in literature ${ }^{18,27}$.

\section{CONCLUSION}

Cumin is mostly cultivated for its numerous medicinal, nutraceutical, and pharmaceutical properties. It also has a wide use in beverage, food, liquor, medicine, perfume, and toiletry. The medicinal and health potentials of cumin are mainly attributed to its antioxidant, antibacterial, antifungal, anti-inflammatory, antidiabetic, insecticide, and immunomodulatory properties. The various parts of the cumin plant (leaves, shoot, root, and flowers) also contain similar and different chemical compounds. More studies are, however, required to unravel novel components and applications of cumin.

\section{ABBREVIATIONS}

eNOS: Endothelial nitric oxide synthase,

hsCRP: high-sensitivity C-reactive protein

IL-6: Interleukin-6

TNF- $\alpha$ : Tumor necrosis factor-alpha

TRX1: Thioredoxin 1

TRXR1: Thioredoxin reductase 1

\section{ACKNOWLEDGMENTS}

The authors greatly acknowledge the technical support from the Department of Biology, Faculty of Applied Sciences, Universiti Teknologi MARA, 40450, Shah Alam, Selangor, Malaysia.

\section{AUTHOR'S CONTRIBUTIONS}

Abdulmutalib Alabeed Allaq, Norrizah Jaafar Sidik, Aziyah Abdul-Aziz, and Idris Adewale Ahmed were all involved in the review conceptualization and first draft of the manuscript. Then All authors were involved in the first review and subsequent completion of the review. And all the authors were then involved in the critical review of the manuscript, final review, and editing. All authors read and approved the final 
Table 2: Common important chemicals in cumin essential oils

\begin{tabular}{|c|c|c|c|}
\hline Compound & Chemical category & Part/Extract & References \\
\hline $\begin{array}{l}\text { Cumin } \\
\text { aldehyde }\end{array}$ & Essential oil & $\begin{array}{l}\text { Seed and } \\
\text { fruit }\end{array}$ & $\begin{array}{l}\text { Kedia et al. }(2015)^{19} \text {; Moghaddam et al. }(2015)^{14} \text {; Jafari, Sat- } \\
\text { tari and Ghavamzadeh }(2017)^{1} \text {; Petretto et al. }(2018)^{10} \text {. }\end{array}$ \\
\hline$\gamma$-Terpinine & Essential oil & $\begin{array}{l}\text { Seed and } \\
\text { fruit }\end{array}$ & $\begin{array}{l}\text { Naeini, Naderi, and Shokri, }(2014)^{23} \text {; Kedia et al. }(2015)^{19} \text {; } \\
\text { Moghaddam et al. }(2015)^{14} \text {; Jafari, Sattari and Ghavamzadeh } \\
(2017)^{1} \text {. }\end{array}$ \\
\hline$\alpha$-Sabinin & Essential oil & Seed & Jafari, Sattari and Ghavamzadeh $(2017)^{1}$. \\
\hline$\alpha$-Flandren & Essential oil & Seed & Jafari, Sattari and Ghavamzadeh $(2017)^{1}$. \\
\hline$\alpha$-Kadinin & Essential oil & Seed & Jafari, Sattari and Ghavamzadeh $(2017)^{1}$. \\
\hline p-Cymene & Essential oil & Seed & $\begin{array}{l}\text { Naeini, Naderi, and Shokri, }(2014)^{23} \text {; Kedia et al. }(2015)^{19} \text {; } \\
\text { Moghaddam et al. }(2015)^{14} \text {; Petretto et al. }(2018)^{10}\end{array}$ \\
\hline$\alpha$-Pinene & Essential oil & Fruit & $\begin{array}{l}\text { Naeini, Naderi, and Shokri, }(2014)^{23} \text {; Moghaddam et al. } \\
(2015)^{14} \text {; Petretto et al. }(2018)^{10}\end{array}$ \\
\hline$(-)-\beta$-Pinene & Essential oil & Seed & Kedia et al. $(2015)^{19}$; Petretto et al. $(2018)^{10}$ \\
\hline $\begin{array}{l}\alpha- \\
\text { Phellandrene, }\end{array}$ & Essential oil & Fruit & Moghaddam et al. (2015) ${ }^{14}$; Petretto et al. $(2018)^{10}$; \\
\hline$\alpha$-Terpinene & Essential oil & Fruit & Moghaddam et al. $(2015)^{14}$; Petretto et al. $(2018)^{10}$ \\
\hline$\alpha$-Terpineol & Essential oil & Fruit & $\begin{array}{l}\text { Naeini, Naderi, and Shokri, }(2014)^{23} \text {; Moghaddam et al. } \\
(2015)^{14} \text {; Petretto et al. }(2018)^{10}\end{array}$ \\
\hline Safranal & Essential oil & Fruit & Moghaddam et al. $(2015)^{14}$ \\
\hline Limonene & Essential oil & Seed & Naeini, Naderi, and Shokri, $(2014)^{23}$; Petretto et al. $(2018)^{10}$. \\
\hline 1,8-Cineole & Essential oil & Seed & Naeini, Naderi, and Shokri, $(2014)^{23}$; Petretto et al. $(2018)^{10}$. \\
\hline Linalool & Essential oil & Seed & Naeini, Naderi, and Shokri, $(2014)^{23}$; \\
\hline Linalyl acetate & Essential oil & Seed & Naeini, Naderi, and Shokri, $(2014)^{23}$; \\
\hline $\begin{array}{l}\alpha \text {-Terpineol } \\
\text { acetate }\end{array}$ & Essential oil & Seed & Naeini, Naderi, and Shokri, $(2014)^{23}$; \\
\hline Geraniol & Essential oil & Seed & Naeini, Naderi, and Shokri, $(2014)^{23}$; \\
\hline Methyl eugenol & Essential oil & Seed & Naeini, Naderi, and Shokri, $(2014)^{23}$; \\
\hline Sabinene & Essential oil & Seed & Naeini, Naderi, and Shokri, $(2014)^{23}$; Petretto et al. $(2018)^{10}$. \\
\hline Terpinolene & Essential oil & Seed & Naeini, Naderi, and Shokri, $(2014)^{23}$; Petretto et al. $(2018)^{10}$. \\
\hline$\alpha$-Thujene & Essential oil & Seed & Naeini, Naderi, and Shokri, $(2014)^{23}$; Petretto et al. $(2018)^{10}$. \\
\hline Myrcene & Essential oil & Seed & Naeini, Naderi, and Shokri, $(2014)^{23}$; Petretto et al. $(2018)^{10}$. \\
\hline$\gamma$-Terpineol & Essential oil & Seed & Naeini, Naderi, and Shokri, $(2014)^{23}$; Petretto et al. $(2018)^{10}$. \\
\hline Daucene & Essential oil & Seed & Petretto et al. $(2018)^{10}$ \\
\hline d3-Carene & Essential oil & Seed & Petretto et al. (2018) ${ }^{10}$ \\
\hline Pinocarvone & Essential oil & Seed & Petretto et al. $(2018)^{10}$ \\
\hline Cariophyllene & Essential oil & Seed & Petretto et al. (2018) ${ }^{10}$ \\
\hline $\begin{array}{l}\text { Farnesene-(Z)- } \\
\beta\end{array}$ & Essential oil & Seed & Petretto et al. $(2018)^{10}$ \\
\hline Germacrene D & Essential oil & Seed & Petretto et al. $(2018)^{10}$ \\
\hline$\alpha$-Acoradiene & Essential oil & Seed & Petretto et al. $(2018)^{10}$ \\
\hline Carotol & Essential oil & Seed & Petretto et al. (2018) ${ }^{10}$ \\
\hline
\end{tabular}


Table 3: Most important biological activities of cumin

\begin{tabular}{|c|c|c|c|}
\hline Properties & Model & Findings & References \\
\hline Antioxidant & In vitro & $\begin{array}{l}\text { The antioxidant activities of cumin essential } \\
\text { oils are positively correlated with their phe- } \\
\text { nolic contents which increase at stages of in- } \\
\text { termediate and premature. }\end{array}$ & $\begin{array}{l}\text { Moghaddam et al. }(2015)^{14} \text {; } \\
\text { Mohamed, Hamed and } \\
\text { Fouda }(2018)^{24} \text {. }\end{array}$ \\
\hline Antibacterial & In vitro & $\begin{array}{l}\text { Ethanolic extracts of C. cyminum antibac- } \\
\text { terial effect have against Staphylococcus au- } \\
\text { reus. }\end{array}$ & Mostafa et al. $(2018)^{25}$. \\
\hline Antifungal & In vitro & $\begin{array}{l}\text { C. cyminum essential oils have a broad- } \\
\text { spectrum antifungal effect against several } \\
\text { pathogenic Candida species }\end{array}$ & $\begin{array}{l}\text { Naeini, Naderi, and Shokri } \\
(2014)^{23} \text {; Minooeian- } \\
\text { haghighi, Sepehrian and } \\
\text { Shokri, }(2017)^{22} \text {; Petretto et } \\
\text { al. }(2018)^{10} \text {. }\end{array}$ \\
\hline $\begin{array}{l}\text { Anti- } \\
\text { inflammatory }\end{array}$ & $\begin{array}{l}\text { Animal model } \\
\text { (rat) }\end{array}$ & $\begin{array}{l}\text { Nine weeks of intervention improved } \\
\text { plasma nitric oxide, decreased the systolic } \\
\text { blood pressure up-regulated the gene } \\
\text { expression of eNOS, Bcl-2, TRX1, and } \\
\text { TRXR1; and down-regulated Bax, TNF- } \alpha \text {, } \\
\text { and IL-6. }\end{array}$ & $\begin{array}{l}\text { Kalaivani, Saranya and Ra- } \\
\text { makrishnan }(2013)^{26} \text {; Srini- } \\
\text { vasan }(2018)^{27} \text {. }\end{array}$ \\
\hline $\begin{array}{l}\text { Antidiabetic and } \\
\text { anti-inflammatory }\end{array}$ & Human & $\begin{array}{l}\text { Eight weeks of intervention improved fast- } \\
\text { ing blood glucose, glycosylated hemoglobin } \\
\text { as well as serum levels of insulin, TNF- } \alpha, \text { C- } \\
\text { reactive protein, and adiponectin. }\end{array}$ & $\begin{array}{l}\text { Jafari, Sattari and } \\
\text { Ghavamzadeh, }(2017)^{1}\end{array}$ \\
\hline Insecticide & Insect vectors & $\begin{array}{l}\text { Cumin essential oils were very active against } \\
\text { adults of } M \text { Msca persicae (LC50=3.2 } \mathrm{ml} / \mathrm{L} \text { ) } \\
\text { and } M . \text { domestica (LD50=31.8 } \mu \mathrm{g} / \mathrm{adult} \text { ). }\end{array}$ & Benelli et al. $(2018)^{21}$. \\
\hline Immunomodulatory & $\begin{array}{l}\text { Animal (Swiss } \\
\text { albino mice) }\end{array}$ & $\begin{array}{l}\text { Cumin administration significantly in- } \\
\text { creased } \mathrm{CD} 4 \text { and } \mathrm{CD} 8 \text { ( } \mathrm{T} \text { cells) count } \\
\text { through the modulation of } \mathrm{T} \text { lymphocytes } \\
\text { expression and dose-dependently. }\end{array}$ & $\begin{array}{l}\text { Chauhan et al. }(2010)^{28} \text {; } \\
\text { Srinivasan }(2018)^{27} \text {; Tabarsa } \\
\text { et al. }(2020)^{18} \text {. }\end{array}$ \\
\hline
\end{tabular}

manuscript.

\section{FUNDING}

Not applicable.

\section{AVAILABILITY OF DATA AND MATERIALS}

Not applicable.

\section{ETHICS APPROVAL AND CONSENT TO PARTICIPATE}

Not applicable.

\section{CONSENT FOR PUBLICATION}

Not applicable.

\section{COMPETING INTERESTS}

The authors declare that they have no competing interests.

\section{REFERENCES}

1. Jafari S, Sattari R, Ghavamzadeh S. Evaluation of the effect of 50 and $100 \mathrm{mg}$ doses of Cuminum cyminum essential oil on glycemic indices, insulin resistance and serum inflammatory factors on patients with diabetes type II: A doubleblind randomized placebo-controlled clinical trial. Journal of Traditional and Complementary Medicine. 2017;7(3):332338. PMID: 28725629. Available from: https://doi.org/10.1016/ j.jtcme.2016.08.004.

2. Ahmed IA, Mikail MA, Ibrahim M, Hazali N, et al. Antioxidant activity and phenolic profile of various morphological parts of underutilised Baccaurea angulata fruit. Food Chemistry. 2015;172:778-787. PMID: 25442620. Available from: https://doi.org/10.1016/j.foodchem.2014.09.122.

3. Ibrahim M, Ahmed IA, Mikail MA, Ishola AA, Draman S, Isa ML, et al. Baccaurea angulata fruit juice reduces atherosclerotic lesions in diet-induced Hypercholesterolemic rabbits. Lipids in Health and Disease. 2017;16(134):1-8. PMID: 28687076. Available from: https://doi.org/10.1186/s12944-017-0526-2.

4. Ahmed IA, Mikail MA, Mustafa MR, Ibrahim M, Othman R. Lifestyle Interventions for Nonalcoholic Fatty Liver Disease. Saudi Journal of Biological Sciences. 2019;26:15191524. PMID: 31762620. Available from: https://doi.org/10. 
1016/j.sjbs.2018.12.016.

5. Mikail MA, Zamakshshari N, Abdullah AH. Natunti-aging Skincare: Role and Potential. Biogerontology. 2020;21:293-310. PMID: 32162126. Available from: https: // doi.org/10.1007/s10522-020-09865-z.

6. Rebey IB, et al. Relation between salt tolerance and biochemical changes in cumin (Cuminum cyminum L.) seeds. Journal of Food and Drug Analysis. 2017;25(2):391-402. PMID: 28911682. Available from: https://doi.org/10.1016/j.jfda.2016. 10.00 .

7. Bhatt J, Kumar S, Patel S, Solanki R. Sequence-related amplified polymorphism (SRAP) markers based genetic diversity analysis of cumin genotypes. Annals of Agrarian Science. 2017;15(4):434-438. Available from: https://doi.org/10.1016/ j.aasci.2017.09.001.

8. Kanani P, Shukla YM, Modi AR, Subhash N, Kumar S. Standardization of an efficient protocol for isolation of RNA from Cuminum cyminum. Journal of King Saud University - Science. 2019;31(4):1202-1207. Available from: https://doi.org/ 10.1016/j.jksus.2018.12.008.

9. Thippeswamy N, Naidu KA. Antioxidant potency of cumin varieties-cumin, black cumin and bitter cumin-on antioxidant systems. European Food Research and Technology. 2005;220(5-6):472-476. Available from: https://doi.org/10. 1007/s00217-004-1087-y.

10. Petretto GL, Fancello F, et al. Chemical composition and antimicrobial activity of essential oils from Cuminum cyminum L. collected in different areas of Morocco. Food Bioscience. 2018;22:50-58. Available from: https://doi.org/10.1016/j.fbio. 2018.01.004.

11. Piri R, Moradi A, Balouchi H, Salehi A. Improvement of cumin (Cuminum cyminum) seed performance under drought stress by seed coating and biopriming. Scientia Horticulturae. 2019;257:108667. Available from: https://doi.org/10.1016/j. scienta.2019.108667.

12. Soltani E, Mortazavian SMM, et al. Non-deep simple morphophysiological dormancy in seeds of Cuminum cyminum L. Journal of Applied Research on Medicinal and Aromatic Plants. 2019;15:100222. Available from: https://doi.org/10. 1016/j.jarmap.2019.100222.

13. Ghannadnia M, Haddad R, Zarinkamar F, Sharifi M. Manganese treatment effects on terpene compounds of Cuminum cyminum flowers. Industrial Crops and Products. 2014;53:65-70. Available from: https://doi.org/10.1016/j.indcrop.2013.10.034.

14. Moghaddam M, Miran SNK, Pirbalouti AG, Mehdizadeh L, Ghaderi $Y$. Variation in essential oil composition and antioxidant activity of cumin (Cuminum cyminum L.) fruits during stages of maturity. Industrial Crops and Products. 2015;70:163-169. Available from: https://doi.org/10.1016/j. indcrop.2015.03.031.

15. Rostami H, et al. Development of cumin essential oil nanoemulsions and its emulsion filled hydrogels. Food Bioscience. 2018;26(2018):126-132. Available from: https://doi. org/10.1016/j.fbio.2018.10.010.

16. Zhao Y, et al. Three-stage microwave extraction of cumin (Cuminum cyminum L.) Seed essential oil with natural deep eutectic solvents. Industrial Crops and Products. 2019;140(2019):111660. Available from: https://doi.org/10. 1016/j.indcrop.2019.111660.

17. Milan KSM, Dholakia H, Tiku PK, Vishveshwaraiah P. Enhancement of digestive enzymatic activity by cumin (Cuminum cyminum L.) and role of spent cumin as a bionutrient. Food Chemistry. 2008;110(3):678-683. Available from: https://doi. org/10.1016/j.foodchem.2008.02.062.

18. Tabarsa $M$, et al. Isolation, structural elucidation and immunostimulatory properties of polysaccharides from Cuminum cyminum. Carbohydrate Polymers. 2020;230:115636. PMID: 31887877. Available from: https://doi.org/10.1016/j.carbpol. 2019.115636.

19. Kedia A, Prakash B, Mishra PK, Dwivedy AK, Dubey NK. Biological activities of Cuminum cyminum seed oil and its major components against Callosobruchus chinensis and Sitophilus oryzae. Journal of Asia-Pacific Entomology. 2015;18(3):383388. Available from: https://doi.org/10.1016/j.aspen.2015.04. 012.

20. Packiavathy IASV, et al. Antibiofilm and quorum sensing inhibitory potential of Cuminum cyminum and its secondary metabolite methyl eugenol against Gram negative bacterial pathogens. Food Research International. 2012;45(1):85-92. Available from: https://doi.org/10.1016/j.foodres.2011.10.022.

21. Benelli G, Pavela R, et al. Not just popular spices! Essential oils from Cuminum cyminum and Pimpinella anisum are toxic to insect pests and vectors without affecting non-target invertebrates. Industrial Crops \& Products. 2018;124(2018):236-243. Available from: https://doi.org/10.1016/j.indcrop.2018.07.048.

22. Minooeianhaghighi MH, Shokri H. Antifungal effects of Lavandula binaludensis and Cuminum cyminum essential oils against Candida albicans strains isolated from patients with recurrent vulvovaginal candidiasis. Journal de Mycologie Médicale. 2017;27(1):65-71. PMID: 27751723. Available from: https://doi.org/10.1016/j.mycmed.2016.09.002.

23. Naeini A, Naderi NJ, Shokri H. Analysis and in vitro antiCandida antifungal activity of Cuminum cyminum and Salvadora persica herbs extracts against pathogenic Candida strains. Journal de Mycologie Médicale. 2014;24:13-18. PMID: 24210587. Available from: https://doi.org/10.1016/j.mycmed. 2013.09.006.

24. Mohamed DA, Hamed IM, Fouda KA. Antioxidant and Antidiabetic Effects of Cumin Seeds Crude Ethanol Extract. Journal of Biological Sciences. 2018;18:251-259. Available from: https: //doi.org/10.3923/jbs.2018.251.259.

25. Mostafa AA, et al. Antimicrobial activity of some plant extracts against bacterial strains causing food poisoning diseases. Saudi Journal of Biological Sciences. 2018;25(2):361366. PMID: 29472791. Available from: https://doi.org/10.1016/ j.sjbs.2017.02.004.

26. Kalaivani P, Saranya RB, Ramakrishnan G. Cuminum cyminum, a dietary spice, attenuates hypertension via endothelial nitric oxide synthase and NO pathway in renovascular hypertensive rats. Clinical and Experimental Hypertension. 2013;35(7):534542. PMID: 23402543. Available from: https://doi.org/10.3109/ 10641963.2013.764887.

27. Srinivasan K. Cumin (Cuminum cyminum) and black cumin (Nigella sativa) seeds: traditional uses, chemical constituents, and nutraceutical effects. Food Quality and Safety. 2018;2(1):1-16. Available from: https://doi.org/10.1093/fqsafe/ fyx 031.

28. Chauhan PS, Satti NK, Suri KA, Amina M, Bani S. Stimulatory effects of Cuminum cyminum and flavonoid glycoside on Cyclosporine-A and restraint stress-induced immunesuppression in Swiss albino mice. Chemico-Biological Interactions. 2010;185:66-72. PMID: 20156427. Available from: https://doi.org/10.1016/j.cbi.2010.02.016.

29. Akrami F, Rodríguez-Lafuente A, Bentayeb K, et al. Antioxidant and antimicrobial active paper based on Zataria (Zataria multiflora) and two cumin cultivars (Cuminum cyminum). LWT Food Science and Technology. 2015;60(2):929-933. Available from: https://doi.org/10.1016/j.lwt.2014.09.051.

30. Khalil N, Ashour M, Fikry S, Singab AN, Salama O. Chemical composition and antimicrobial activity of the essential oils of selected Apiaceous fruits. Future Journal of Pharmaceutical Sciences. 2018;4(1):88-92. Available from: https://doi.org/10. 1016/j.fjps.2017.10.004.

31. Taghizadeh SF, et al. Coronatine elicitation alters chemical composition and biological properties of cumin seed essential oil. Microbial Pathogenesis. 2019;130:253-258. PMID: 30910722. Available from: https://doi.org/10.1016/j.micpath. 2019.03.023.

32. Tahir HU, et al. Chemical Composition and Antidiabetic Activity of Essential Oils Obtained from Two Spices (Syzygium aromaticum and Cuminum cyminum). International Journal of Food Properties. 2016;19(10):2156-2164. Available from: https://doi.org/10.1080/10942912.2015.1110166. 